\title{
CBS Gene
}

National Cancer Institute

\section{Source}

National Cancer Institute. CBS Gene. NCI Thesaurus. Code C129049.

This gene plays a role in transsulfuration. 